\title{
Formation of meatiness at young rams at different intensity of body height and alive mass at slaughter
}

\author{
Pomitun I. ${ }^{1}$, Korkh I. ${ }^{2}$, Kosova N. ${ }^{3}$, Boiko N. ${ }^{4}$, Pankiv L. ${ }^{5}$, Riazanov P. ${ }^{6}$ \\ Institute of animal husbandry of NAAS, Tvaryn-nykiv Str., 1a, Kharkiv, 61026, Ukraine, e-mail: ${ }^{1}$ pomitun@ukr.net, \\ 2dr.fox2011@ ukr.net, 33nadokos5@gmail.com, ${ }^{4}$ nat.boiko2011@yandex.ru, ${ }^{5}$ L_panriv@mail.ru, \\ 6ryazanovpavel168@gmail.com
}

The purpose. To determine features of formation of lethal indexes and qualities of meat at young rams at different intensity of body height and alive mass at slaughter. Methods. Complex conventional zootechnical, laboratory and biometric methods of probes. Results. Relative assessment is made of lethal indexes and quality of meat at lambs of different intensity of body height and alive mass at slaughter. The results gained in experience testify to high level of meat productivity of young rams of both groups. At lifetime visual assessment of meat shapes before slaughter their fatness is recognized as average. Whereas the most expressive regularity on martempering meat qualities in all terms of slaughter was in the first group. Young rams of both experimental groups, evaluated according to American scale of quality of carcasses, were treated to class "A". As a result of combination of two critical parameters (age and marbling) all carcasses were classified as "Select" at extent of marbling of mutton from $3(55,6 \%)$ up to $4(44,4 \%)$ points. With heightening alive mass at slaughter marbling of the longest muscle of a back improved. On chemical compound average samples of the mutton, gained from young animals of both groups, to the full matched to demands to high - quality meat raw material and had no authentic differences among themselves. Conclusions. Features of formation of meat productivity at young rams are determined at different intensity of their body height under the influence of feeding with protected from fission in gizzards of the bypass protein additive and different alive mass at slaughter. It was accompanied by increase of prelethal alive mass, masses of fresh - killed carcass, slaughter - weight, dressing percentage, heightening the high - calorie worth of 1 $\mathrm{kg}$ of meat in average samples of forcemeat. At the same time the muscular tissue of young rams with increased intensity of body height (1 group) on the amount of nutritional ingredients in structure of dry matter has appeared less watery and more enriched with protein content at almost equal accumulation of grease and ash.

Key words: young rams, lethal indexes, meat productivity, chemical compound of meat.

DOI: https://doi.org/10.31073/agrovisnyk201905-03

Creating mutton sheep production that will provide for production of young ram and lamb meat in Ukraine suggest obtaining sheep genotypes that have ability for intensive growth within first 4 to 6 after birth and fattening until eight- to ten-month age and are also characterized along with a significant growth energy by a high feed-to-muscle tissue conversion rate and excellent meat quality. At the present tiem, this work in Ukraine is only at the initial stage $[1,2,3]$.

Review of the latest studies and publications. It is worth noting that a number of domestic leading scientists $[4,5,6,7,8,9,10,11,12]$ have been dealing with the issue of sheep meat productivity formation and mutton quality. However, for development of methods for evaluation and formation of desired sheep genotypes and sheep production technologies intended for specific sheep maintenance conditions and obtaining products that would meet both internal and external market demands, profound knowledge of biological features of sheep body formation in the ontogenesis is needed. Knowing these features will allow to reveal sheep body potential and mutton productivity formation regularities and to perform sheep selection and breeding so that to increase the number of pedigree stock and to obtain high-value (from dietic point of view) and cheap mutton. However, studies to evaluate these parameters in sheep of contemporary mutton breeds bred in Ukraine and in their crosses with domestic intrabreed types and breeds have hardly been conducted. Taking all that into account, the above statements make a ground for further more profound studies and define their significance and direction of research. 
Objective of the research. Determining specific features of slaughter parameters and meat quality formation in young rams of various growth rates and slaughter age.

Materials and methods of research. The study was carried out at State Enterprise Experimental Farm Gontarivka of the Institute of Animal Science of the National Academy of Agricultural Science, Vovchansk District, Kharkiv Region. For the study, two groups of Precoce analogue young rams of the Kharkiv intrabreed type with various growth rates within the period after birth to weaning were selected, with 40 animas in each group. The first group was fed roughages (alfalfa hay, corn silage, ground barley and corn) and additionally $150 \mathrm{~g}$ of protein and energy concentrate of protected bypass protein. The second group was fed a similar basic diet, but $150 \mathrm{~g}$ of bypass protein were replaced however with sunflower oil cake, which caused the difference in experimental animal growth rates.

Experimental slaughtering and meat sampling were carried out in three stages: when the animas gained liveweights in groups of about $30 \mathrm{~kg}$ (Stage 1); of about $40 \mathrm{~kg}$ (Stage 2) and $50 \mathrm{~kg}$ (Stage 3) in accordance with the All-Union Institute of Animal Science method, 1978.

Digital data of the experimental studies were biometrically treated at a personal computer using the variation statistics method and MS Excel 2003 application program package. The difference between group was assumed as a significant one with $\mathrm{P}<0.05$.

Results. The results obtained in the study, indicate to a rather high level of meat productivity in both young ram groups. According to the life-time visual evaluation of meat exterior development prior to slaughter, their fatness was determined as medium. However, the most distinctive pattern of improved meat qualities in all preslaughter periods was observed in Group 1 (Table 1). Thus, preslaughter liveweight in the Group 1 young rams of was significantly higher than in their mates in Group 2 at Stage 1 by $3.8 \mathrm{~kg}$ or $12.5 \%(p<0.001)$; at Stage 2 by $3.7 \mathrm{~kg}$ or $9.8 \%$ $(p<0.001)$, at Stage 3 by $3.9 \mathrm{~kg}$ or $8.3 \%(p<0.05)$.

The highest preslaughter liveweight gain in Group 1 was duet to, first of all, a significant increase in hot carcass weight by $2.2 \mathrm{~kg}$ or $18.7 \%$ ( $\mathrm{p}<0.001$ ), by $2.3 \mathrm{~kg}$ or $15.4 \%$ ( $\mathrm{p}<0.05)$; by $2.7 \mathrm{~kg}$ or $13.1 \%$ and in slaughter weight by $2.3 \mathrm{~kg}$ or $19.3 \%$ ( $\mathrm{p}<0.01$ ); by $2.4 \mathrm{~kg}$ or $15.6 \%$ ( $\mathrm{p}<0.01) ; 2.7 \mathrm{~kg}$ or $12.6 \%$, respectively.

Dressing percentage in the both young ram groups was within values similar to those of Precoce sheep. However, use of the bypass protein ensured an advantage of the animals in Group 1 in this parameter at a level of $2.0 \%$.

Measuring carcass weight loss during chilling displayed that the values were higher in the young rams in Group 2: after the Stage 1, 2 and 3 slaughters loss values were on average $5.2 \%, 5.5 \%$ and $3.4 \%$, respectively; while respective values for the young rams of Group 1 made $3.9 \%, 4.3 \%$ and $3.9 \%$.

Quantity of internal fat and its localization in a carcass is of great importance for sheep mutton productivity. It should be noted that during the fattening period the rate of internal crude fat deposition in the young rams was irregular. It increased, with the liveweight increasing, and the highest deposition rate was observed at the Stage 3 slaughter. The highest internal crude fat yield was in the young ram carcasses in Group 1 at the Stages 1 and 2 slaughters and made 1.0 to $1.13 \%$ of preslaughter liveweight, whereas in their mates in Group 2 it was 0.76 to $1.00 \%$. With an increase in the young ram liveweight during the fattening period, the internal crude fat yield reversed to increase in Group 2 and made $1.57 \%$ against $1.44 \%$ in the mates in Group 1 . This affords ground to state that at this age relatively fast-gaining young animals are able to produce carcasses with a lower internal crude fat content, shifting its deposition localizations to intermuscular, subcutaneous and intramuscular areas.

During the commercial evaluation, the Group 1 young ram carcasses were more rounded-off and completely covered with the fat coating, whereas the Group 2 young ram carcasses were less massive and covered in a thinner fat layer. The visual observation of the visceral fat localization displayed that in the young ram abdominal cavity, irrespective of the treatment group, the internal fat covered in a thin layer stomach and large and small intestines and a somewhat thicker strand extended along the spine from the rump to the first thoracic vertebrae. The maximum fat depositions were observed in the loin and rump areas. The kidneys and hearts were completely covered in a layer of visceral fat. 
1. Slaughter parameters of young rams of various growth rates ( $M \pm m, n=3$ animals in a group)

\begin{tabular}{|c|c|c|c|c|c|c|c|c|}
\hline Group & $\begin{array}{l}\text { Preslaughter live- } \\
\text { weight, } \\
\mathrm{kg}\end{array}$ & $\begin{array}{l}\text { Hot carcass } \\
\text { weight, } \\
\mathrm{kg}\end{array}$ & $\begin{array}{l}\text { Carcass } \\
\text { yield, } \\
\%\end{array}$ & $\begin{array}{l}\text { Crude } \\
\text { internal fat weight, } \\
\mathrm{Kг}\end{array}$ & $\begin{array}{l}\text { Internal fat per- } \\
\text { centage, } \\
\%\end{array}$ & $\begin{array}{l}\text { Slaughter weight, } \\
\mathrm{kgr}\end{array}$ & $\begin{array}{l}\text { Dressing per- } \\
\text { centage, } \\
\%\end{array}$ & $\begin{array}{l}\text { Hot skin weight, } \\
\text { kg }\end{array}$ \\
\hline \multicolumn{9}{|c|}{ Stage 1 Slaughter } \\
\hline 1 & $33,93 \pm 0,20^{* * *}$ & $13,73 \pm 0,32^{* * *}$ & 40,5 & $0,34 \pm 0,08$ & 1,00 & $14,08 \pm 0,31^{* *}$ & 41,5 & $3,77 \pm 0,50$ \\
\hline 2 & $30,16 \pm 0,35$ & $11,57 \pm 0,12$ & 38,4 & $0,23 \pm 0,03$ & 0,76 & $11,80 \pm 0,11$ & 39,1 & $3,37 \pm 0,35$ \\
\hline \multicolumn{9}{|c|}{ Stage 2 Slaughter } \\
\hline 1 & $41,53 \pm 0,15^{* * *}$ & $17,43 \pm 0,49^{*}$ & 42,0 & $0,47 \pm 0,05$ & 1,13 & $17,90 \pm 0,47^{* *}$ & 43,1 & $4,73 \pm 0,03$ \\
\hline 2 & $37,83 \pm 0,18$ & $15,10 \pm 0,21$ & 39,9 & $0,39 \pm 0,03$ & 1,00 & $15,49 \pm 0,19$ & 40,9 & $4,20 \pm 0,20$ \\
\hline \multicolumn{9}{|c|}{ Stage 3 Slaughter } \\
\hline 1 & $51,57 \pm 0,44^{*}$ & $23,09 \pm 0,24^{*}$ & 44,8 & $0,74 \pm 0,09$ & 1,44 & $23,83 \pm 0,21^{*}$ & $46,2^{*}$ & $4,33 \pm 0,12$ \\
\hline 2 & $47,63 \pm 1,28$ & $20,41 \pm 0,58$ & 42,8 & $0,75 \pm 0,14$ & 1,57 & $21,16 \pm 0,71$ & 44,4 & $3,90 \pm 0,31$ \\
\hline
\end{tabular}

Notes. ${ }^{*} p<0,05 ;{ }^{* *} p<0,01 ;{ }^{* * *} p<0,01-$ significant difference between Group 1 and Group 2 
It was established that the young rams in the both experimental groups had been evaluated to belong to Grade A in accordance with the US Carcass Quality Grading. As a result of combination of two basic parameters age and marbling score, all the carcasses were graded as Select, with mutton marbling score varying from 3 (55.6\%) to 4 (44.4\%). With the liveweight being higher at the slaughter time, the Longissimus dorsi marbling score increased. At the same time, muscle tissue colour varied from light pink at the Stage 1 and 2 slaughters to bright red at the Stage 3 slaughter. However, muscle tissue colour expression did not correlate with the growth rate. Subcutaneous fat colour varied with a preslaughter liveweight increase from white to white with a yellowish shade.

The obtained data proved that not only the absolute hot carcass weight increased, but the relative hot carcass weight and internal crude fat content did too. Moreover, the young rams in Group 1 dominated in hot skin and head weight, however the significance between the two groups was at the level of a trend.

Individual determination of the absolute viscera weight allowed to establish that despite the lack of statistically significant difference between the group weights, the young rams in Group 1 had liver developed better by $4.2 \%$, lungs by $6.7 \%$, kidneys by $22.2 \%$ at the Stage 1 slaughter; liver by $9.3 \%$, spleen by $66.7 \%$, heart by $20.0 \%$, lungs by $13.2 \%$, kidneys by $22.2 \%$ at the Stage 2 slaughter. At the Stage 3 slaughter they displayed a significant increase in the spleen weight by $29.6 \%(p<0.05)$ and heart weight by $16.7 \%(p<0.05)$. Regarding the increase in the weight of other internal organs, it was different and varied from $16.7 \%$ to

$19.7 \%$. The advantage of the Group 1 animals over the Group 2 mates in absolute weight of internal organs was probably due to their better growth rate.

Relative yield of internal organs was also strongly related to young ram growth rate and was determined by their total weight. With an increase in the slaughter liveweight, the preslaughter liveweight gain increased by $69.7 \%$ and $57.9 \%$, hot carcass weight by $68.2 \%$ and $76.4 \%$, internal fat by 2.1 and 3.1 times; slaughter weight by $69.2 \%$ and $82.4 \%$; slaughter yield by $4.7 \%$ and $5.3 \%$; liver weight by 2.0 and 1.8 times; spleen by 1.8 and 1.4 times; heart by 1.5 and 1.3 times; lungs by 2.3 and 2.0 times and kidneys by 1.3 times in both cases.

The Group 1 young rams had advantage over Group 2 in total half-carcass flesh weight by $14.8 \%$, including Grade 1 by $14.5 \%$ and Grade 2 by $16.4 \%$.

The total meatiness index that shows ratio of the chilled carcass flesh content to the carcass length varied from $4.8 \mathrm{~kg}$ to $5.6 \mathrm{~kg}$ at the Stage 1 slaughter; from $3.6 \mathrm{~kg}$ to $3.8 \mathrm{~kg}$ at the Stage 2 slaughter; from $2.8 \mathrm{~kg}$ to $3.3 \mathrm{~kg}$ at the Stage 3 slaughter. It is worth noting, that with both young ram growth rate and slaughter liveweight increased, the ratio decreased due to an intensive increase in the carcass length.

Mutton chemical composition provides insight into changes in the slaughter products and particularly in the muscle tissue. In their chemical composition, the average mutton samples taken from young animals of the both groups were found to meet requirements for high quality raw meat and did not have significant differences between the groups. Alternatively, muscle tissue of the young rams in Group 1 as compared with that of the mates in Group 2 was less watery, taking into account the quantity of food components in the dry matter, by $1.01 \%$ to $3.6 \%$ and had higher protein content by $0.82 \%$ to $4.2 \%$, with the weight percentages of deposited fat and ash being nearly the same.

The young ram meat in Group 1 had a better physiological maturity as this score was higher at the Stage 1 slaughter by $6.3 \%$; at the Stage 2 slaughter by $14.3 \%$ and at Stage 3 slaughter by $3.3 \%$. At the same time, the advantage in the dry matter to moisture ratio (maturity rate) of Group 1 increased more notably by $5.3,5.3$ and $17.6 \%$, respectively, when the protein to fat ratio approached the optimum, as compared with the mates in Group 2, which meets consumer requirements for nutritional and taste qualities of meet. The ascertained fact of the direct proportional relationship of increased flesh in semi carcasses to nearly the same fat content accounted for the increased caloric value per kilogram of product and increased protein content in average ground meat samples in Group 1 which made 3,4-7,8\% as compared with the values in Group 2.

According to the active acidity value determined twenty-four hours after the slaughter, the Group 1 young animal muscle tissue had a higher alkali value $(\mathrm{pH}=5.74-5.89$ against $5.74-5.80)$ and a lower water-binding capacity by $0.73-4.15 \%$ as compared with those of the Group 2 young animals. The measured active acidity values did not exceed the limits and testified to the normal course of the after-slaughter process of glycolysis in the muscle tissue of the young rams of the both groups. 
Other parameters differed negligibly and did not have significant differences between the groups.

\section{Implications}

Young sheep meat productivity formation features was established at different intensity of growth under protected from digestion in rumen bypass-protein supplement feeding influence and slaughter timing. The higher preslaughter live weight by $8.3 \%$ to $12.5 \%$, hot carcass weight by $13.1 \%$ to $18.7 \%$, slaughter weight by $12.6 \%$ to $19.3 \%$, slaughter yield by $1.8 \%$ to $2.4 \%$, caloric value of kilogram of average meat samples increased were by $3.4-7.8 \%$ manifested. At the same time, the muscle tissue of the animals evaluated by the quantity of feed components in the dry matter was found to be less watery by $1.01 \%$ to $3.6 \%$ and with a higher protein content by $0.82 \%$ to $4.2 \%$, with amounts of deposited fat and ash being nearly the same.

\section{List of references}

1. Pomitun, I. A., Kosova, N. O., Zolotarova, S. A., Rossoxa, V. I., Pankiv, L. P., Bojko, N. V. et al. (2016). Metody stvorennya ovecz myasnogo ta udoskonalennya tonkorunnogo myaso-vovnovogo napryamu produktyvnosti [Methods of Creation of Mutton Sheep and Improvement of Fine-Fleece Mutton-Wool Producing Sheep]. Kharkiv [in Ukraian].

2. Pomitun, I. A., Korx, I. V., Kosova, N. O., Pankiv, L. P., Bojko, N. V., Zo-lotarova, S. A., Ryazanov, P. O. (2016). Vykorystannya krosbrydyngu porid merynolandshaf i prekos dlya pidvyshhennya myasnoyi produktyvnosti ovecz. [Using Crossbreeding of Merinolandschaf and Precoce to Increase Sheep Mutton Productivity]. Problemy zooinzheneriyi ta veterynarnoyi medycyny: zb. nauk. pr. Xark. derzh. zoovet. akad.-Problems of Animal Science and Veterinary Medicine: Collection of Treatises of the Kharkiv State Animal Science and Veterinary Academy. Kharkiv, KhDZVA, 32 (1), 97-107. (Ser. S.-g. nauky) [in Ukrainian].

3. Pomitun, I. A., Ryazanov, P. O., Bojko, N. V., Pomitun, L. I., Kravczov, A. V. (2013). Formuvannya bazhanyx genotypiv, genealogichnoyi struktury stada ta rezultaty ocinky ovecz, stvoryuvanogo specializovanogo myasnogo napryamu produktyvnosti [Formation of Desired Genotypes, Genealogical Structure of the Flock and Results of Evaluating Special Mutton Sheep Bred]. Naukovo-texnichnyj byuleten-Scientific Technical Bulletin. Kharkiv: Institute of Animal Science of the National Academy of Agricultural Sciences], 110, 141-147 [in Ukrainian].

4. Zharuk, P. G., Zaruba, K. V. (2016). Myasna produktyvnist molodnyaku ovecz cygajskoyi porody ta pomisej z askanijskymy krosbredamy [Meat Productivity of Young Tsigai Sheep and Their Crosses with Askaniya Crossbreds]. Naukovyj visnyk Nacz. un-tu bioresursiv i pryrodokorystuvannya Ukrayiny -Scientific Bulletin of National University of Biological Resources and Management of Natural Resources of Ukraine. Kyiv, 236, 146-154 (Ser. Texnologiya vyrobnycztva i pererobky produkciyi tvarynnycztva) [in Ukrainian].

5. Chokan, T. V. (2014) Myasna produktyvnist ovecz ukrayinskoyi girskokarpatskoyi porody [Mutton Productivity of Ukrainian Highland Carpathian

Sheep]. Texnologiya vyrobnycztva i pererobky produkciyi tvarynnycztva-Ani-mal Product Processing: Collection of Treatises of the Bila Tserkva Agricultural University. Bila Tserkva, 2, 143-146 [in Ukrainian].

6. Poxyl, V. I., Lesnovska, O. V. (2013). Osoblyvosti rostu i rozvytku ovecz riznyx myasnyx genotypiv [Characteristics of Growth and Development of Sheep of Various Genotype]. Tvarynnycztvo Ukrayiny-Animal Production of Ukraine, 11, 7-10 [in Ukrainian].

7. Poxyl, V. I., Lesnovska, O. V. (2012). Zabijni yakosti ovecz riznogo poxodzhennya [Slaughter Qualities of Sheep of Various Origin]. Naukovyj visnyk „Askaniya-Nova”-Scientific Journal «Askania Nova». Nova Kakhovka: PIEL, 5(1), 171-174 [in Ukrainian].

8. Kremenchuk, L. V. (2010). Intensyvnist rostu ta zabijni yakosti baranciv na rannomu etapi ontogenezu zalezhno vid viku materiv karakulskoyi porody [Growth Rates and Slaughter Qualities of Young Rams in the Early Ontogenesis in Relation to the Age of Karakul Dams]. Agrarnyj visnyk Prychornomorya-Agrarian Bulletin of the Black Sea Region: Collection of Treatises of the Odesa Agricultural University. Odesa, 54, 47-51 (Ser. S.-g. nauky) [in Ukrainian].

9. Kudryk, N. A. (2007). Vidgodivelni yakosti ta myasna produktyvnist askanijskogo porodnogo typu bagatoplidnyx karakulskyx ovecz [Fattening Qualities and Meat Productivity of the Askaniya Breed Type of Multiparous Kara- 
kul Sheep]. Vivcharstvo-Sheep Production: Cross-Sectoral Subject Collection. Nova Kakhovka: PIEL, 34, 59-64 [in Ukrainian].

10. Soloxa, I. M. (2006). Myasna produktyvnist baranchykiv riznoyi porodnosti [Meat Production of Young Rams of Various Breeds]. Visnyk Dnipropetrovskogo derzh. agrar. un-t-Bulletin of Dnipropetrovsk State Agricultural University. 2, 108-110 [in Ukrainian].

11. Sanudo C. Breed Effect on Carcase and Meat Quality of Suckling Lambs // Meat Science. 1997. Vol. 46. №4. P. 357-365.

12. Zygoyiannis D. Carcass composition in lambs of Greek dairy breeds of sheep. Anim. Prod. 1990. Vol. 50. P. 261-269. 